\title{
Foreword: Partisanship and the U.S. National Interest
}

\author{
David L. Boren
}

Our dysfunctional political system is a national embarrassment.

Whether the issue is the budget, gun control, health care, or immigration, the executive and legislative branches are unable to work together to solve the nation's problems. Partisan posturing has pushed out bipartisanship and compromise. Cooperation between liberals and conservatives is becoming a quaint memory.

U.S. foreign policy is increasingly hamstrung by partisan politics as well. From Europe to the Middle East to China, Democrats and Republicans not only cannot agree; they are disinclined to work together to promote the national interest. Tom Brokaw's “Greatest Generation" was comprised of men and women who risked their lives to advance the national interest. Where is that spirit now? Senator Arthur Vandenberg, a conservative who was the champion of bipartisanship during World War II, laid the foundations for the Marshall Plan and a bipartisan foreign policy. Where are his successors today?

When I chaired the Senate Intelligence Committee in the 1980 s and 1990s, I was able to work with my Republican colleagues on bipartisan solutions to our nation's security challenges. Intelligence Committee voting was usually unanimous. In fact, we never divided along strict party lines in any of our rare roll call votes.

Those days are long gone. Voting in most congressional committees today divides along partisan lines. The wise agreement that "politics should stop at the water's edge" has become a relic of the past.

David L. Boren is the president of the University of Oklahoma. He has also served Oklahoma as governor (1975-79) and U.S. senator (1979-94). He was the longest-serving chair of the Senate Intelligence Committee. 
During my fifteen years in the Senate, I learned that partisan divisions over foreign policy have consequences. They complicate pursuit of the national interest. They distress our foreign allies and friends. They present to the world a distorted picture of America. At their most damaging, they turn friends into foes and make more difficult the task of advancing our national interest. When foreign policy becomes partisan, the national interest suffers.

In 2008, I wrote in A Letter to America that "partisanship clearly becomes destructive when partisan advantage is elevated above the national interest." Examples abound of partisan politics disrupting orderly governance. During the winter of 2012-13, the "fiscal cliff," sequestration, and the debt ceiling dominated political debate. Liberals and conservatives representing the extreme wings of their parties refused to compromise, allowing ideological purity to trump the national interest. During that same period, partisan disputes marred the confirmation hearings for President Obama's national security team. The incoming secretary of defense, former senator Chuck Hagel, received more "no" votes in the Senate than any previous candidate for that office, while confirmation of the new CIA director was held up for weeks by partisan wrangling.

For eleven years, some on the right in the Senate have blocked passage of the UN Convention on the Law of the Sea, despite support for passage from the business community, the military, and the public. More recently, a group of senators rejected the UN Convention on the Rights of Persons with Disabilities, even though the convention mirrored the much admired Americans with Disabilities Act of 1990, which passed the Senate with bipartisan support twentythree years ago. In both cases, those in opposition held that the conventions ceded a piece of American sovereignty to the United Nations, an international body that conservatives love to hate.

The American people tolerate partisanship in foreign policy in part because they have little interest in foreign affairs-until something goes wrong. Nor do our citizens show much interest in American history. Despite the fact that we are a practical, problem-solving people, we are cynical towards government and doubtful that Washington will ever accomplish anything that directly affects us. Such cynicism is no surprise given that the picture that emerges in our media is of a people in decline, of special interest groups dominating politics, of vast sums of money lubricating our political system, of declining participation in civic organizations and activities.

But as I wrote in A Letter to America, "In all the ways that matter, we Americans have so many reasons to believe that our future can be even greater than our past." We prize a culture that is dynamic, pragmatic, and innovative. We prize our openness to change, which has long been America's default position. And we have surmounted obstacles in the past. In this instance, we can start by 
trying to understand why and how hyper-partisanship has come to dominate our political discourse.

In The Politics of American Foreign Policy, Peter Gries analyzes partisanship_-affecting both domestic and foreign policy — and finds its origins in the deeply embedded ideologies that are changing our electoral landscape. Ideological self-sorting, aided by the gerrymandering that once again took place after the 2010 census, is dividing America into warring political camps. The majority of congressional districts have now become hyper-partisan-so red or blue that general elections are often mere formalities. Instead, a majority of the members of Congress face their stiffest competition in the primaries, where the 10 to 20 percent of eligible voters who do vote usually represent the extreme wings of their parties. "For the most part," Professor Gries writes, "politicians today are not elected by the median voters in their districts. Their job security, instead, depends upon a small minority within their parties." In these circumstances, candidates for office must cater to the ideological extremes, setting the stage for a partisan approach to governing and a bias against-even a fear of compromise.

Professor Gries argues that while partisanship and ideology tend to go together, ideology is the more fundamental driver of political attitudes and behavior. The Politics of American Foreign Policy explores the nuances of American ideology, including its complex of values, beliefs, and motivations. While partisanship can be fluid, ideology appears more stable, frequently passed from generation to generation. For instance, the once solidly Democratic South is now the solidly Republican South. The partisan alignment has flipped, but the underlying ideologies have changed only marginally.

Since ideological positions are strongly held and change only slowly, does this mean that our dysfunctional political system will be with us for years to come? The very red and very blue congressional districts that dot the political landscape today are unlikely to change much - at least until the 2020 census, when redistricting and the gerrymandering that will inevitably follow it might partially reshape the electoral landscape, giving median voters a louder voice and reducing the clout of the extreme wings of both political parties.

For this to happen, the ideologies that undergird partisanship will have to change too. Internationalists in both parties must unite to oppose isolationists. Put another way, liberals and conservatives should try to move towards the middle, which is the only place where a bipartisan foreign policy can take root.

As I wrote in A Letter to America, "The history of our nation is one of almost unbroken progress. While there have been temporary ups and downs, each generation has been able to say that it has left America better in most ways than it found it." Despite our broken political system, I still believe that state- 
ment is correct. Our pragmatism, our determination, and our free and creative society will help us find ways to right the political ship and steer towards the goals we all share. As Peter Gries explains, the roots of hyper-partisanship have flourished in the extreme ideologies cultivated by the far left and far right of both our political parties. We understand the problem. The task for Americans now is to promote dialogue, cooperation, and compromise between liberals and conservatives, to bring our two great parties together in a joint effort to solve the problems facing us. We have done it in the past. We can do it now. 
The Politics of American Foreign Policy 
